\title{
Sugárterápia hatása a beültethető szívritmus-szabályozók múködésére
}

\author{
Kohári Mária', Kószó Renáta², Hideghéty Katalin², Vámos Máté1, \\ Sághy László
}

\author{
${ }^{1}$ Szegedi Tudományegyetem Általános Orvostudományi Kar, ${ }^{1}$ II. sz. Belgyógyászati Klinika és Kardiológia \\ Központ, ${ }^{2}$ Onkoterápiás Klinika, Szeged
}

Levelezési cím: Dr. Kohári Mária, e-mail: kohari.maria@med.u-szeged.hu

\begin{abstract}
Az elmúlt néhány évtizedben a pacemaker-, defibrillátor- és reszinkronizációs eszközbeültetések száma emelkedő tendenciát mutat, mint ahogyan a daganatos megbetegedések előfordulása is. Ezáltal egyre több ritmusszabályozó eszközzel élö beteg szorul sugárkezelésre az onkológiai terápia részeként. A radioterápia alatt átmeneti vagy tartós készülékdiszfunkció jöhet létre, ezért kiemelten fontos a kezelés és az utánkövetés alapos megtervezése, mind a sugárterapeuta, mind az elektrofiziológus részéről. Jelen közlemény az evidenciaként rendelkezésre álló vizsgálatokon és nemzetközi ajánlásokon keresztül összegzi azokat a szempontokat, amelyek ismerete nélkülözhetetlen a ritmusszabályozóval élő, sugárterápiára kerülő betegeknél.
\end{abstract}

Kulcsszavak: ritmusszabályozó, CIED, sugárterápia, neutronkilépés

The effect of radiotherapy on the function of cardiovascular implantable electronic devices (CIEDs)

In the last decades, the number of pacemaker, defibrillator and resynchronization device implantations has been continuously increasing, just like the incidence of malignancies. Thus, more and more patients living with cardiovascular implantable electronic devices (CIEDs) are receiving radiation therapy as part of cancer treatment. Considering that transient or permanent device dysfunction may occur during radiotherapy, careful radiation treatment planning and device follow-up has an important role throughout the oncologic treatment. The current review provides a summary of the available evidences and international recommendations, which should be considered in patients undergoing radiotherapy.

Keywords: cardiovascular implantable electronic device, CIED, radiotherapy, neutron production

\section{Bevezetés}

Az elmúlt néhány évtizedben a pacemaker- (PM), kardioverter-defibrillátor- (ICD) és reszinkronizációs eszköz- (CRT) implantációk száma világszerte megemelkedett. Európában több mint 500000 ember él PM-mel, 85000 felett van az ICD-vel és 51000 fölött mérhető a CRT-vel rendelkező betegek száma (1). A populáció öregedésével további növekedés várható a beültetett elektromos kardiológiai eszközök (CIED) számában. $A z$ egyre idősödő populációban a társbetegségek, többek között a daganatos megbetegedések száma is emelkedik, így egyre nagyobb arányban kerülnek rit- musszabályozóval élő betegek sugárkezelésre. Ismert, hogy ezen onkológiai terápiák jelentős hatással lehetnek a beültetett eszközök működésére, ezért kiemelten fontos a megfelelő kommunikáció és a kezelés megtervezése e betegek ellátása kapcsán mind a sugárterapeuta, mind a kardiológus, elektrofiziológus részéröl. A jelenlegi közlemény célja, hogy a rendelkezésre álló klinikai vizsgálatok eredményeit, valamint az Amerikai Szívritmus Társaság (HRS) 2017-ben megjelent nemzetközi szakértöi konszenzusnyilatkozatának (2), továbbá a Német Sugárterápiás Társaság és a Német Kardiológiai Társaság (DEGRO/DGK) 2020-ban validált

A kézirat 2020. 05. 13 -án érkezett a szerkesztőségbe, 2020. 06. 04-én került elfogadásra. 
ajánlásának (3) legfontosabb elemeit foglalja össze a magyar nyelvű közönség számára, megteremtve ezzel egy esetleges későbbi magyar szakmai ajánlás megszületésének alapjait.

\section{A sugárterápia biofizikai alapjai és módszerei}

A sugárterápia a rosszindulatú daganatok és egyéb proliferatív betegségek kezelésének fontos részét képezi. Az ionizáló sugárzással végzett kezelés és az annak során bekövetkező hatások megértéséhez szükséges néhány definíciót tisztázni. A sugárkezelés során a szövetekben elnyelt dózis (energia/tömeg) mértékegysége a Gray (Gy = joule/kg). Az egész testtérfogaton belül, a daganatot magába foglaló céltérfogatban elnyelt energia, a gócdózis befolyásolja a terápiás hatást. A sugárterápia során a leadandó teljes dózist (összgócdózist) kisebb részekre, frakciókra kell osztani (frakciódózis), hogy a környező, egészséges szövetek kevésbé károsodjanak. Ezen frakciók adagolása különböző sémák szerint történik, az alapbetegségtől és a daganattípustól függően. A sugárterápiának két alapvető módszere a teleterápia (távolbesugárzás) és a brachiterápia (közelbesugárzás). Az előbbinél nagy energiájú fotonsugárzás, elektron-, proton- és neutronsugárzás, valamint nehézionok, leggyakrabban szénionok alkalmazására kerül sor. Az utóbbi évtizedek technikai fejlődése lehetővé tette sokmezős vagy forgómezős besugárzás, illetve hadronok esetén raszter szkennelés formájában a céltérfogat szelektív besugárzását, az ezen kívüli ép szövetek, beültetett készülékek (így CIED-ek) védelmét, a direkt dózis minimalizálását. Nagyobb energiák alkalmazása során megnő a másodlagos neutronok mennyisége (különösen >15 MV energiájú, intenzitásmodulált sugárkezelés (IMRT), illetve passzív szkennelt nehézion-terápia esetén), amelyek jelentős szerepet játszanak a CIED-ek meghibásodásában (4). Brachiterápia során zárt sugárforrást vagy sugárforrásokat juttatunk a daganatba, vagy annak közelébe, ami a gyakorlatban testüregbe vagy szövetközi térbe történő forráselhelyezést jelent. A sugárzás intenzitása a távolság négyzetével arányosan csökken, a dózisgrádiens meredek, így biztosítható az egészséges szövetek védelme. A meredek dózisesés és az alkalmazott, 20-380 keV energiák révén a brachiterápia csekély hatással bír a CIED-ekre, amelyek dózisa általában alacsonyan tartható. Ezidáig nem észleltek brachiterápiával kapcsolatos, sugárindukálta CIED-komplikációt. A holland irányelvek szerint ezért a brachiterápia a teleterápiával ekvivalens módon kezelhető, amíg szélesebb körü irodalmi adat nem áll rendelkezésre (5).

A klinikai gyakorlatban az alábbi sugárminőségeket alkalmazzák:

- A lineáris gyorsítók által létrehozott fotonsugárzás a leggyakrabban alkalmazott sugárminőség. A fotonenergia jellemzésére a névleges gyorsítófe- szültséget használjuk (MV), amely a sugárnyaláb energiájára utal. A lineáris gyorsítók jellemzően 4-23 MV-os fotonsugárzást képesek előállítani.

- Az elektronsugárzásra jellemző, hogy kisebb mélységben nyelődik el, mint a fotonsugárzás, így alkalmas felületes elváltozások kezelésére, ahol a mélyebben fekvő szövetek megkímélése szükséges.

- A protonterápia is egyre szélesebb körben hozzáférhető modalitás, amelynek során ciklotron vagy szinkrotron segítségével állítanak elő akár 250 MeV energiájú protonokat. A dózis leadása a protonok energiájától függő mélységben hirtelen történik (Bragg-csúcs), így kisebb a dózis a céltérfogat előtti ép szövetekben, mint fotonsugárnyaláb esetén. A céltérfogat tervezett dózisa mögött is nagy dózisesés következik be, így a célterület mögötti szöveteket alig éri dózisterhelés.

- Ugyanez az elnyelési tulajdonság jellemző nehézionnyaláb esetén is, azonban a kevés centrumban elérhető szénionsugárzás biológiai hatékonysága is nagyobb, két-háromszorosa a fotonsugárzásénak. A céltérfogat pontos dozírozását a tumor térfogategységei vastagságának megfelelő Bragg-csúcs-,,kiszélesítéssel” lehet elérni, amely passzív szórással vagy aktív szkenneléssel történhet.

- Meg kell említeni még a ma már ritkán alkalmazott, gyors neutronokkal végzett sugárkezelést és a termikus, epitermikus neutronokkal végzett bór neutronbefogás-terápiát (BNCT). Az atommagrészecske-sugárzás e formáinál nagy mennyiségü direkt neutron érheti a ritmusszabályozó eszközöket.

Konformális sugárterápia esetén a besugárzási mező a céltérfogat alakját követi, így nagy dózisok ebben a volumenben jelennek meg. Bár a sugárkezelés célzottan történik, elkerülhetetlen, hogy a céltérfogaton kívül a pácienst ne érje alacsony dózisú sugárterhelés. A másodlagos fotonsugárzás egyik forrása a direkt sugárzással besugárzott területekről szóródó sugárzás. A másodlagos sugárzáshoz azonban a „neutronszenynyezés” is hozzájárul, amelynek mértéke a sugárterápia során alkalmazott sugárnyaláb energiájától, minőségétől és a moduláció technikájától függ. 10 MV-nál nagyobb energiájú fotonbesugárzás, $20 \mathrm{MeV}$ energiát meghaladó elektronbesugárzás vagy passzíve modulált nyalábú protonbesugárzás esetén a neutronkilépés többszörös (2).

\section{A sugárterápia eszko̊zo̊kre kifejtett hatása}

Az Amerikai Orvosi Fizikusok Szövetségének (AAPM) 1994-es ajánlása alapján 2 Gy az a sugárdózis, amely felett az eszközkárosodás esélye jelentősen emelkedik (6). Ez az érték a 1980-as évek vizsgálataiból szárma- 
zik, és számos ajánlásban a mai napig ez a 2 Gy küszöbérték szerepel. Jóllehet, újabb klinikai vizsgálatok eredményei egyre inkább azt mutatják, hogy még az 5 Gy-ig emelkedő, eszközt érő sugárdózis és az eszközdiszfunkció között sem egyértelmű az összefüggés (7-9).

A sugárterápia következtében kialakuló készülékmalfunkció mögött a következő közvetlen okok állhatnak:

1. Az eszközök fejlődése során a komplementer fémoxid félvezető (CMOS) áramkörök alkalmazása került elötérbe, itt a sztochasztikus hatás a legnagyobb jelentőségü. $E$ hatás következtében leginkább az eszköz memóriájában vagy a paraméterekben következhet be „átállítódás” (reset), amely többségében programozható és ritkán jár irreverzibilis következménnyel. Ez a diszfunkció a másodlagos neutronképződés következménye $(7,8)$.

2. A lineáris gyorsító működése során létrejövő elektromágneses interferencia miatt kialakuló „oversensing” következtében ingerlésgátlás (inhibíció) vagy nem megfelelő érzékelés (inappropriate detekció) is létrejöhet.

\section{Evidenciák a ritmusszabályozóval élö betegek sugárkezelésével kapcsolatosan}

A sugárterápia eszközökre kifejtett hatását dominálóan in vitro körülmények között vizsgálták, azonban több kis esetszámú és néhány nagyszámú klinikai vizsgálat eredménye is rendelkezésre áll.

$A z$ in vitro vizsgálatok során fantomban elhelyezett ritmusszabályozók besugárzását követően elemezték a jelentkező hatásokat (1. táblázat). A vizsgálatok során direkt és szórt besugárzás hatásait vizsgálták alacsonyabb és magasabb energiáknál, különböző sugárminőségek esetén.

Az in vivo vizsgálatok obszervációs és kohorszvizsgálatokon alapulnak (2. táblázat), randomizált vizsgálatok nem elérhetőek. A legnagyobb esetszámú vizsgálatban Zaremba és munkatársai 462 PM, 54 ICD, 25 biventrikuláris-pacemaker (CRT-P) és 19 biventrikuláris ICD (CRT-D) utánkövetését végezték el sugárterápia után. 24 beteg esetében helyezték át a készüléket a sugárterápia előtt. $A$ készülékdiszfunkciók esetében a medián nyalábenergia 16,5 MV, a tumor kumulatív dózisának mediánértéke 46,5 Gy volt. Összesen 14 eszköznél jelentkezett diszfunkció (3,1\%). 11 esetben részleges vagy teljes átállítódás, amely programozással megoldható volt, két esetben a gyártó segítségével történt átprogramozás, egy esetben pedig megemelkedett pitvari stimulációs küszöb. A sugárkezelés során a $15 \mathrm{MV}$-ot meghaladó nyalábenergia-érték volt a készülékdiszfunkció legerősebb prediktora (10). Grant retrospektív vizsgálatában összesen 123 PM-et és 92 ICD-t tanulmányozott 6-18 MV foton- és elektronterápia után, valamint gammakéssel végzett sugárkezelést követően, különös tekintettel a nagyobb energia esetén keletkező neutronsugárzás károsító hatására. Az utánkövetés során 18 esetben (8,4\%) figyeltek meg diszfunkciót: öt esetben memóriaátállítódást, nyolc esetben paraméterátállítódást, két esetben korai teleplemerülést, három esetben átmeneti „oversensinget”, egy ICD esetében pedig inadekvát készülékműködést (8). A vizsgálatban neutrontermelő sugárkezelés során jelentkezett az öszszes CIED-diszfunkció.

Az in vivo és in vitro vizsgálatok eredményeit is áttekintve kiemelendő, hogy az eszközök diszfunkciójában azok magasabb életkora, a nagy energiájú sugárnyalábokkal végzett terápia és a kezelés során keletkező neutronszennyezés játszik lényeges szerepet. A sugárkezelés során alacsony arányban átmeneti, az esetek egy részében készülékprogramozással megoldható problémák (programozott paraméterek változása, rögzített adatok elvesztése, inadekvát készülékmüködés) jelentkeztek, elhanyagolható számban az eszköz interrogálhatatlansága, korai teleplemerülés fordult elö.

Kiemelendő még Gauter-Fleckenstein és munkatársainak prospektív vizsgálata, amelyben 160, CIED-et viselő beteg részesült sugárkezelésben konformális, IMRT- vagy sztereotaxiás technikával, $6 \mathrm{MV}$ foton$(n=146)$ és elektronnyalábokkal $(n=14)$ a 2019-es DEGRO/DGK-ajánlásnak (11) megfelelően, míg 40 betegnél az 1994-es AAPM-irányelvek (6) szerint jártak el, és konformális technikával 10-23 MV fotonnyalábokkal $(n=39)$ és elektronnyalábokkal végezték a kezelést (3). Az AAPM-ajánlás szerint kezelt csoportban 39, fotonnal besugárzott beteg közül hétnél léptek fel komplikációk, egy páciensnél inadekvát defibrilláció jelentkezett. Az összes, 6-23 MV fotonenergiákkal kezelt betegre a CIED-probléma kialakulásának relatív kockázata $6 \mathrm{MV}$ feletti energiáknál 9,03-nak $(95 \%$ Cl: 5,24-15,55) bizonyult. A DEGRO/DGK ajánlása alapján kezelt betegek közül 147, fotonalapú sugárkezelésben részesülő betegnél nem volt CIED-komplikáció, bár a CIED dózisa akár az 5,37 Gy-t is elérte. A tizenhárom, elektronnal kezelt beteg közül egy PM-készülék beteggel kapcsolatos adatokat veszített. A DEGRO/DGK-ajánlás alkalmazása így hatékonyan megelőzte a sugárkezeléssel kapcsolatos CIED-szövődményeket a fotonnal kezelt betegeknél. Javaslatuk alapján a fotonenergiák 6 MVben való korlátozása, az ICD-kben a defibrillációs kezelés felfüggesztése, a betegek kockázatalapú követése és a CIED-ek közvetlen besugárzásának kerülése szükséges a napi gyakorlatban.

\section{A malfunkció betegre kifejtett hatása}

A sugárterápia következtében létrejövő diszfunkció az eszköz típusától függően okozhat tüneteket. Pacemakerek esetében ilyen tünet lehet az ingerlés felfüggesztése miatt létrejövő bradycardia, aszisztólia és 


\begin{tabular}{|c|c|c|c|c|c|c|}
\hline Szerző & Év & $\begin{array}{l}\text { Eszköz } \\
(\mathrm{db})\end{array}$ & Típus & $\begin{array}{l}\text { Sugárminö- } \\
\text { ség; kumula- } \\
\text { tív dózis }\end{array}$ & Energia & $\begin{array}{l}\text { Észlelt nemkívánatos } \\
\text { esemény }\end{array}$ \\
\hline $\begin{array}{l}\text { Mouton et } \\
\text { al. (15) }\end{array}$ & 2002 & 96 & $\begin{array}{l}\text { PM } \\
\text { (különböző } \\
\text { korú eszközök, } \\
11 \text { gyártó) }\end{array}$ & $\begin{array}{l}\text { foton, direkt } \\
\text { besugárzás; } \\
>140 \text { Gy }\end{array}$ & $18 \mathrm{MV}$ & $\begin{array}{l}\text { • >10\%-os érzékelésváltozás: } 38 \text { PM } \\
\text { (2-130 Gy); } \\
\text { >10 sec-os inhibíció: } 35 \text { PM (0,15-74 } \\
\text { Gy); } \\
\text { - Tartós inhibíció: } 12 \text { PM (0,5-170 Gy) }\end{array}$ \\
\hline $\begin{array}{l}\text { Mollerus et } \\
\text { al. (16) }\end{array}$ & 2014 & 8 & $\begin{array}{l}\text { ICD ( } 4 \text { korszerű } \\
\text { és } 4 \text { régi esz- } \\
\text { köz) }\end{array}$ & $\begin{array}{l}\text { foton, direkt } \\
\text { besugárzás; } \\
\text { 131,11 Gy }\end{array}$ & $6 \mathrm{MV}$ & $\begin{array}{l}\text { - Nem volt meghibásodás: } 4 \text { korszerű } \\
\text { ICD (130 Gy); } \\
\text { - Sokkterápia elmaradása: } 4 \text { régi ICD }\end{array}$ \\
\hline $\begin{array}{l}\text { Zaremba et } \\
\text { al. (12) }\end{array}$ & 2014 & 12 & $\begin{array}{l}\text { PM (10 új } \\
\text { eszköz), ICD } \\
\text { ( } 2 \text { explantált } \\
\text { eszköz) } \\
\text { ( } 5 \text { gyártó) }\end{array}$ & $\begin{array}{l}\text { foton, szórt } \\
\text { sugárzás; } \\
150 \text { Gy }\end{array}$ & 6-18 MV & $\begin{array}{l}\text { 6 MV } \\
\text { - Telemetria elvesztése: } 1 \text { PM (150 Gy); } \\
18 \text { MV } \\
\text { - Memóriaadatok elvesztése: } 1 \text { ICD } \\
\text { ( } 44 \text { Gy), } \\
\text { - Idő előtti teleplemerülés: } 1 \text { PM, } \\
\text { - Nem programozható: } 1 \text { PM, } \\
\text { - Reset to back-up pacing mode: } 3 \text { PM }\end{array}$ \\
\hline $\begin{array}{l}\text { Kapa et al. } \\
\text { (17) }\end{array}$ & 2008 & 20 & $\begin{array}{l}\text { ICD (12), } \\
\text { CRT-D (8) } \\
\text { (3 gyártó) }\end{array}$ & $\begin{array}{l}\text { foton, szórt } \\
\text { sugárzás; } \\
4 \text { Gy }\end{array}$ & $6 \mathrm{MV}$ & Nem észleltek malfunkciót \\
\hline $\begin{array}{l}\text { Hashimoto } \\
\text { et al. (18) }\end{array}$ & 2012 & 4 & $\begin{array}{l}\text { ICD } \\
\text { (új eszközök) }\end{array}$ & $\begin{array}{l}\text { proton, passzív } \\
\text { szórással; } \\
107 \text { Gy }\end{array}$ & $200 \mathrm{MeV}$ & $\begin{array}{l}\text { - Memória- vagy power-reset: } 1 / 15 \text { Gy; } \\
\text { - Power-on-reset (= safety back-up } \\
\text { mode): } 1 / 50 \mathrm{~Gy} \text {; } \\
\text { - Nem volt irreverzibilis károsodás }\end{array}$ \\
\hline $\begin{array}{l}\text { Zecchin et } \\
\text { al. (4) }\end{array}$ & 2016 & 59 & $\begin{array}{l}\text { PM (34), ICD } \\
\text { (25) (explantált } \\
\text { eszközök) }\end{array}$ & $\begin{array}{l}\text { foton, direkt } \\
\text { besugárzás; } \\
70 \text { Gy }\end{array}$ & $15 \mathrm{MV}$ & $\begin{array}{l}\text { - Mágnesfunkció-deaktiváció: } 1 \text { ICD, } \\
\text { - Programozhatatlan eszköz: } 3 \text { ICD, } \\
\text { - Programozásváltozás: } 1 \text { ICD, } \\
\text { - Pulzusgenerátor-hiba: } 4 \text { ICD, } \\
\text { - Elektromos reset: } 1 \text { ICD; } \\
\text { - Elektromos reset: } 4 \text { PM, } \\
\text { - Back-up VVI mode: } 2 \text { PM }\end{array}$ \\
\hline $\begin{array}{l}\text { Koivunoro } \\
\text { et al. (19) }\end{array}$ & 2011 & 2 & $\begin{array}{l}\text { PM ( } 2 \text { korszerü } \\
\text { típus, } 1 \text { gyártó) }\end{array}$ & $\begin{array}{l}\text { epitermikus ne- } \\
\text { utron; dózisráta: } \\
150-400 \mu S v / h\end{array}$ & $\begin{array}{l}\text { Fluxus: } \\
(0,5 \pm 0,2 \%) \times \\
10^{12} \mathrm{n}^{0} / \mathrm{cm}^{2} \\
(1,1 \pm 0,1 \%) \times \\
10^{12} \mathrm{n}^{0} / \mathrm{cm}^{2}\end{array}$ & $\begin{array}{l}\text { - Az eszköz interrogálhatatlan: } 1 \text { PM, } \\
\text { - Back-up VVI mode: } 1 \text { PM }\end{array}$ \\
\hline $\begin{array}{l}\text { Trigano et } \\
\text { al. (20) }\end{array}$ & 2012 & 14 & $\begin{array}{l}\text { PM (explantált } \\
\text { eszközök, } \\
4 \text { gyártó) }\end{array}$ & neutron & $\begin{array}{l}30-50 \mathrm{MeV} \\
\text { Fluxus: } 1 \times 10^{9} \mathrm{n} / \\
\mathrm{cm}^{2}, 5 \times 10^{9} \mathrm{n}^{0} / \mathrm{cm}^{2} \\
1 \times 10^{10} \mathrm{n} \% \mathrm{~cm}^{2}\end{array}$ & $\begin{array}{l}\text { •Elektronikai reset” (emelkedés, csök- } \\
\text { kenés a jobb kamrai ingerlési frekven- } \\
\text { ciában): } 6 \text { PM (magas fluxusszinteken) }\end{array}$ \\
\hline $\begin{array}{l}\text { Nakamura } \\
\text { et al. (21) }\end{array}$ & 2020 & 4 & $\begin{array}{l}\text { PM (2), CRT-P } \\
(2)\end{array}$ & $\begin{array}{l}\text { foton; dózistel- } \\
\text { jesítmény: } 4-14 \\
\text { Gy/perc (6 MV), } \\
\text { 4-24 Gy/perc } \\
(10 \mathrm{MV}), \text { FFF }\end{array}$ & $6 \mathrm{MV}, 10 \mathrm{MV}$ & $\begin{array}{l}\text { - Ingerlés felfüggesztése a besugárzás } \\
\text { időtartama alatt minden eszköznél }\end{array}$ \\
\hline
\end{tabular}

Röviditések: $\mathrm{CIED}=$ beültethetö elektromos kardiológiai eszköz, $C R T-D=$ kardiális reszinkronizációs terápia defibrillátorral, ICD=implantálható kardioverter defibrillátor, FFF=Flattening Filter Free, $\mathrm{PM}=$ pacemaker

következményes eszméletvesztés. CRT-k esetében a szívelégtelenség tüneteinek fokozódása léphet fel. Magasabb ingerlési frekvenciára történő átállítódás következtében palpitáció, malignus ritmuszavarok, ICD-k esetében pedig „oversensing” kapcsán akár inappropriate sokkleadás is bekövetkezhet $(7,8,12)$.

A CIED-ket, PM-eket és ICD-ket gyártó cégek nem rendelkeznek egyértelmű ajánlásokkal a sugárterápiát ille- tően, azonban egyhangúan javasolják, hogy a generátor ne essen a besugárzási mezőbe (2). A terápia során a besugárzási mezőbe eső eszközök akadályozzák az adekvát sugárkezelést, így ezekben az esetekben indokolt lehet a generátor áthelyezése. Ilyen döntés esetén azonban az eszköz áthelyezéséből származó következményekkel is számolnunk kell a beavatkozások kapcsán (13). 

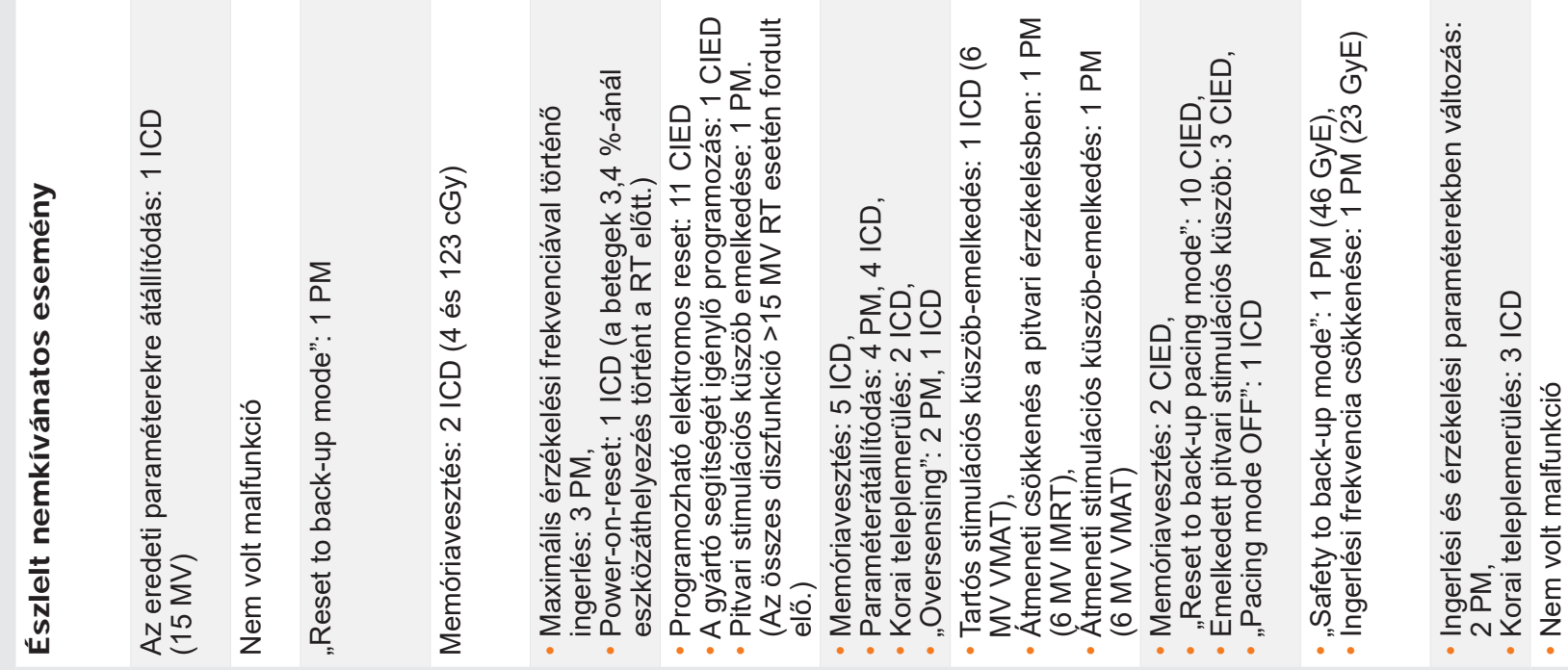

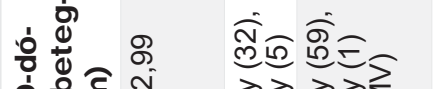

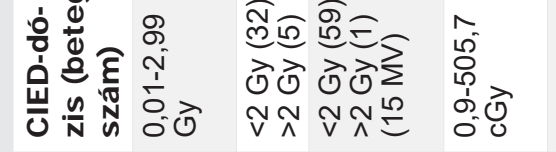

तु ते $\quad$ वे

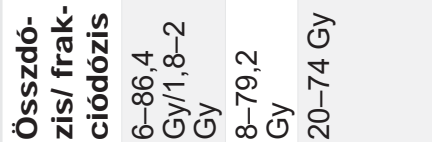

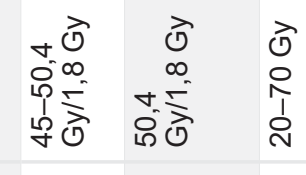

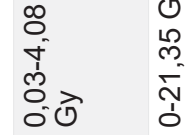

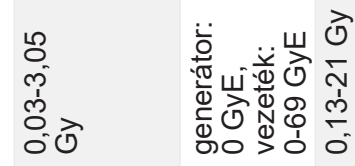

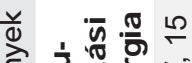

:

$\stackrel{10}{\circ}$

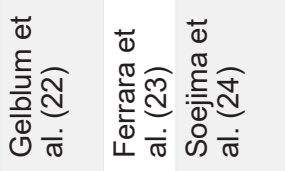

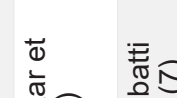

竞

$\stackrel{\infty}{\text { ก }}$

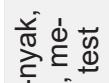

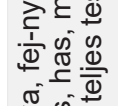

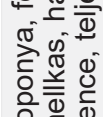

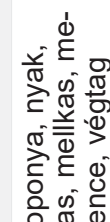

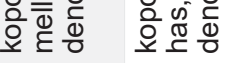
뉴 ڤे̀े

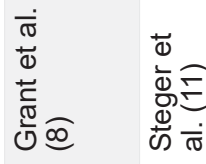



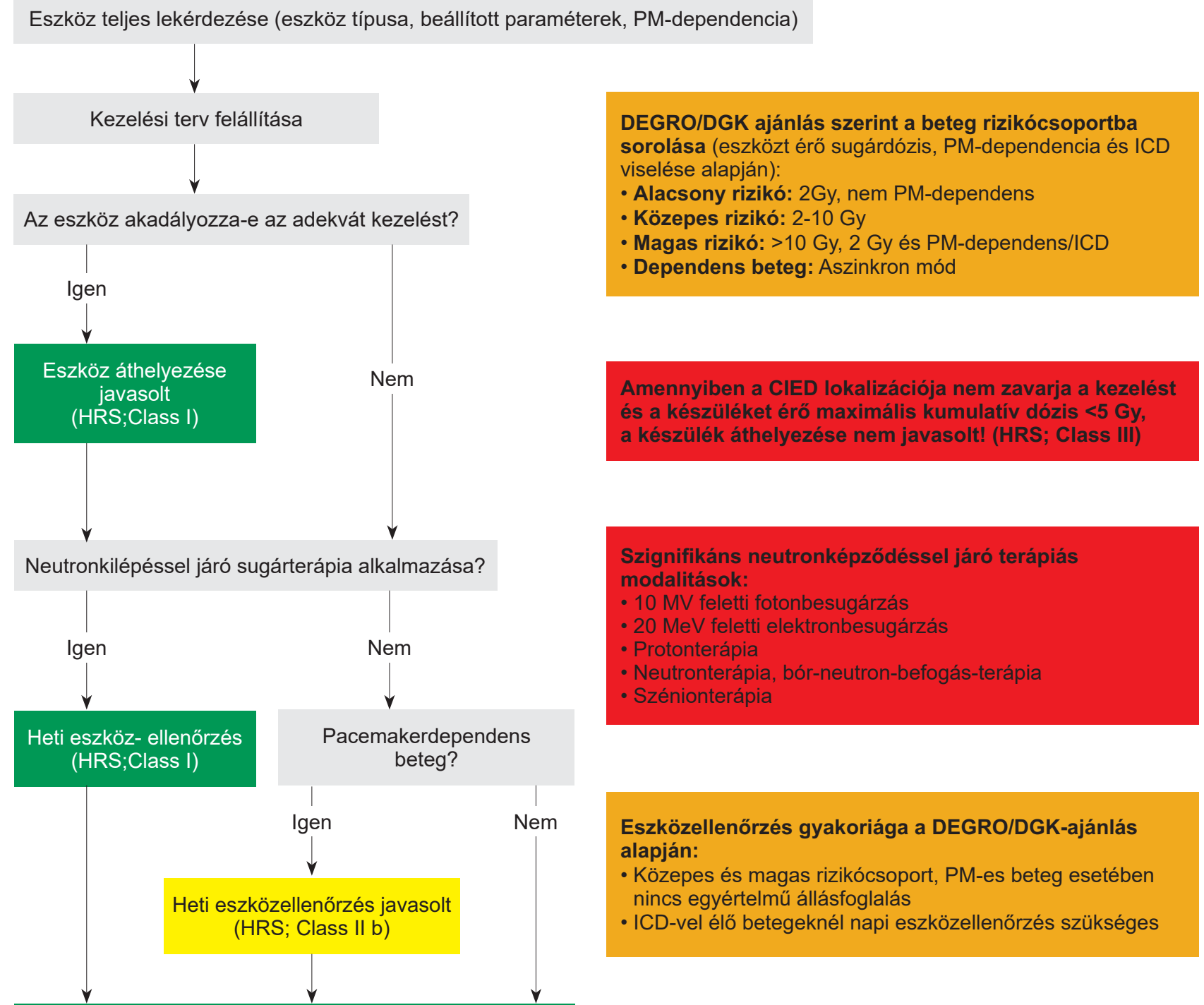

A sugárkezelés végén teljes eszközinterrogáció javasolt (HRS; Class I)

1. ÁBRA. Beültethető eszközzel élő betegek sugárkezelése kapcsán szükséges teendők. A 2017-es nemzetközi konszenzus és a 2015-ös DEGRO/DGK irányelve alapján készült egyesített folyamatábra, amely a sugárterápiára kerülő betegnél szükséges intézkedéseket tartalmazza (CIED=beültethető elektromos kardiológiai eszköz, DEGRO/DGK=Német Sugárterápiás Társaság/Német Kardiológiai Társaság, HRS= Amerikai Szívritmus Társaság, ICD=implantálható kardioverter defibrillátor, PM=pacemaker)

\section{Ajánlás a CIED-del élö betegek sugárkezelésével kapcsolatos teendőkre}

A ritmusszabályozóval élő személy sugárkezelésének megtervezésekor elengedhetetlen az aritmológus és a sugárterapeuta együttmüködése. A 2017-es nemzetközi konszenzusdokumentum (2) és a 2015-ös DEGRO/ DGK-irányelv (14), valamint a 2020 -as validált algoritmus (3) alapján a sugárterápiára kerülő betegnél szükséges intézkedések a következők (1. ábra).

A sugárterápia megkezdése elött mindenképpen szükséges az aritmológus és sugárterapeuta közötti konzultáció, amely során a következő feladatokat kell elvégezni:
1. Szükséges minden eszköz lekérdezése, mert a kezelést végző munkacsoportnak ismernie kell az eszköz pontos típusát (PM vagy ICD). Ellenőrizni kell az elektródák mérhető paramétereit, az esetleges PM-dependenciát, valamint rögzíteni kell, hogy mennyi a beállított nyugalmi és maximális ingerlési frekvencia (maximal tracking és sensor rate).

2. A kezelés elött mind a nemzetközi, mind a DEGRO/ DGK-ajánlás alapján tisztázni kell, hogy mekkora az alkalmazott fotonnyaláb energiája, valamint várhatóan mekkora az eszközt érő sugárdózis. Ezen adatok alapján a DEGRO/DGK ajánlása szerint a betegek alacsony (2 Gy, nem PM-dependens és primer profi- 
laktikus ICD), közepes (2-10 Gy vagy 2 Gy és PM-dependencia vagy korábbi malignus aritmia) és magas rizikójú (>10 Gy) csoportba sorolandók. A különböző rizikócsoportokban eltérő szintü monitorozás és szakorvosi felügyelet elrendelése lehet szükséges.

3. Tisztázandó, hogy a terápia során várható-e neutronszennyezés. A HRS-konszenzus alapján a kezelés során javasolt a kisebb neutronprodukcióval járó modalitás alkalmazása. A vizsgálatok alapján a ritmusszabályozók diszfunkciójának legerősebb prediktora a neutronkilépéssel járó sugárkezelés, amely 10 MV feletti energiák esetén szignifikáns. Direkt neutronbesugárzás esetén még nagyobb körültekintéssel szükséges eljárni, epitermikus neutronnal végzett bórneutron-befogás terápia pedig nem alkalmazható CIED-del élő betegeknél.

4. Az eszköz áthelyezése megfontolandó, figyelembe véve az ezzel járó esetleges következményeket, ha az eredeti CIED-lokalizáció zavarja a megfelelő kezelést.

5. Amennyiben a CIED elhelyezkedése nem zavarja a kezelést és az azt érő maximális kumulatív dózis az 5 Gy-t nem éri el, akkor a készülék áthelyezése nem javasolt.

\section{A sugárterápia alatt megfontolandó teendő́k}

1. A betegek monitorizálására vonatkozóan is eltérő a német és nemzetközi javaslat. A nemzetközi ajánlás alapján elegendő folyamatos audiovizuális kontaktus fenntartása a sugárterápiában részesülő beteggel, azonban a német irányelv értelmében a közepes és magas rizikójú betegeknél szükséges folyamatos EKG-, noninvazív és oxigénszaturáció-monitorozás. A DEGRO/DGK-ajánlás alapján közepes rizikójú betegek esetében külső defibrillátor és pacemaker-készültség, valamint alapszintű újraélesztésben (BLS) jártas személy jelenléte is szükséges. Magas rizikójú betegek kezelése során kardiológus vagy aneszteziológus jelenléte javasolt.

2. Pacemakerrel élő betegnél dependencia és neutrontermelő sugárterápia esetén hetente egyszer teljes körü eszközellenőrzés javasolt a nemzetközi irányelvek szerint.

3. Ugyancsak különbség figyelhető meg a német és a nemzetközi ajánlásban a pacemakerek átprogramozására vonatkozóan. A német ajánlás PM-dependens betegek esetében az aszinkron üzemmódba állítást javasolja. ICD-t viselő betegnél az antitachycardia terápia felfüggesztése mérlegelendő, ebben az esetben viszont folyamatos monitorozás és defibrillátorkészültség lehet szükséges.

\section{Sugárterápiát kővetően szülkséges teendő́k}

1. A DEGRO/DGK ajánlása alapján ICD-vel élő betegek esetében a sugárterápiát követően minden eset- ben készülékellenőrzés szükséges, erről azonban a nemzetközi konszenzusdokumentum nem nyilatkozik.

2. A nemzetközi konszenzus szerint a sugárkezelés utolsó frakcióját követően teljes körű eszközellenőrzés szükséges.

\section{O̊sszefoglalás}

A sugárterápia CIED-ekre kifejtett hatásáról szóló vizsgálatok száma összességében alacsony, a rendelkezésre álló adatok alapján azonban a káros következmények általában ritkák és jól előre jelezhetők. A nagyobb vizsgálatok eredményei alapján leginkább a másodlagos neutronképződés tehető felelőssé a CIED-ek meghibásodásáért. Az eszközök direkt expozíciója és kumulatív dózisa, továbbá a terápia során alkalmazott nyalábenergia is meghatározó az eszközdiszfunkció kockázatában. Mindezek figyelembevétele mellett a beültetett eszköz típusa, valamint a beteg PM-dependenciája igényel különös figyelmet. A sugárterápiában részesülő és CIED-del élő betegek biztonságos kezeléséhez elengedhetetlen a sugárterápiás és az elektrofiziológiai munkacsoport folyamatos együttmüködése valamint figyelembe véve a különböző ajánlások eltérő javaslatait, szükséges minden intézetben az erre vonatkozó közös protokoll kialakítása.

\section{Nyillatkozat}

A szerzők kijelentik, hogy az összefoglaló közlemény megírásával kapcsolatban nem áll fenn velük szemben pénzügyi vagy egyéb lényeges összeütközés, összeférhetetlenségi ok, amely befolyásolhatja a közleményben bemutatott eredményeket, az abból levont következtetéseket vagy azok értelmezését.

\section{Irodalom}

1. Raatikainen MJ, et al. Statistics on the use of cardiac electronic devices and electrophysiological procedures in the European Society of Cardiology countries: 2014 report from the European Heart Rhythm Association. Europace 2015; 17(Suppl 1): i1-75. DOI: 10.1093/europace/euu300

2. Indik JH, et al. 2017 HRS expert consensus statement on magnetic resonance imaging and radiation exposure in patients with cardiovascular implantable electronic devices. Heart Rhythm 2017; 14(7): e97-e153. DOI: 10.1016/j.hrthm.2017.04.025

3. Gauter-Fleckenstein B, et al. Effectivity and applicability of the German DEGRO/DGK-guideline for radiotherapy in CIED-bearing patients. Radiother Oncol 2020. DOI:10.1016/j.radonc.2020.01.006 4. Zecchin $M$, et al. Malfunction of cardiac devices after radiotherapy without direct exposure to ionizing radiation: mechanisms and experimental data. Europace 2016; 18(2): 288-93. DOI:10.1093/europace/euv250

5. Coen W, Hurkmans JLK, Bing S Oei, Ad JJ Maas, GJ Uiterwaal, et al. Management of radiation oncology patients with a pacemaker or ICD: A new comprehensive practical guideline in The Netherlands. Radiation Oncology 2012; 7: 198. 
6. Marbach JR SM, Van Dyk J, Wolbarst AB. Managemnet of radiation oncology patients with implanted cardiac pacemakers: Reports of AAPM Task Group No. 34. Med Phys 1994; 21(1): 85-90. DOI: 10.1118/1.597259

7. Brambatti $M$, et al. Management of patients with implantable cardioverter-defibrillators and pacemakers who require radiation therapy. Heart Rhythm 2015; 12(10): 2148-54. DOI: 10.1016/j. hrthm.2015.06.003

8. Grant JD, et al. Radiotherapy-Induced Malfunction in Contemporary Cardiovascular Implantable Electronic Devices: Clinical Incidence and Predictors. JAMA Oncol 2015; 1(5): 624-32. DOI: 10.1001/jamaoncol.2015.1787

9. Makkar A, et al. Effect of radiation therapy on permanent pacemaker and implantable cardioverter-defibrillator function. Heart Rhythm 2012; 9(12): 1964-8. DOI: 10.1016/j.hrthm.2012.08.018 10. Zaremba T, et al. Risk of device malfunction in cancer patients with implantable cardiac device undergoing radiotherapy: a population-based cohort study. Pacing Clin Electrophysiol 2015; 38(3): 343-56. DOI: 10.1111/pace.12572

11. Steger F, et al. Radiotherapy of patients with cardiac implantable electronic devices according to the DEGRO/DGK guideline-is the risk of relevant errors overestimated? Strahlenther Onkol 2019; 195(12): 1086-1093. DOI: 10.1007/s00066-019-01502-0

12. Zaremba $\mathrm{T}$, et al. The effect of radiotherapy beam energy on modern cardiac devices: an in vitro study. Europace 2014; 16(4): 612-6. DOI: 10.1093/europace/eut249

13. Poole JE, et al. Complication rates associated with pacemaker or implantable cardioverter-defibrillator generator replacements and upgrade procedures: results from the REPLACE registry. Circulation 2010; 122(16): 1553-61. DOI: 10.1161/CIRCULATIONAHA.110.976076

14. Gauter-Fleckenstein $B$, et al. DEGRO/DGK guideline for radiotherapy in patients with cardiac implantable electronic devices. Strahlenther Onkol 2015; 191(5): 393-404. DOI: 10.1007/s00066015-0817-3

15. Mouton J, et al. Influence of high energy photon beam irradiation on pacemaker operation. 2002; 47(16): 2879-93. DOI: 10.1088/0031-9155/47/16/304

16. Mollerus $M$, et al. Radiation tolerance of contemporary implantable cardioverter-defibrillators. J Interv Card Electrophysiol 2014; 39(2): 171-5. DOI: 10.1007/s10840-013-9861-z

17. Kapa, S., L.F., Charles R. Blackwell, Michael G. Herman, Paula J.
Schomberg and David L. Hayes, Effects of Scatter Radiation on ICD and CRT Function. Pacing Clin Electrophysiol 2008; 31:727-732. DOI: 10.1111/j.1540-8159.2008.01077.x

18. Hashimoto TIT, Hashii H, Kumada $H$, Tada $H$, Okumura T, Tsuboi K, Sakae T, Aonuma K, Sakurai H. Influence of secondary neutrons induced by proton radiotherapy for cancer patients with implantable cardioverter defibrillators. Radiation Oncology 2012; 7: 10. DOI: 10.1186/1748-717X-7-10

19. Koivunoro $\mathrm{H}$, et al. Epithermal neutron beam interference with cardiac pacemakers. Appl Radiat Isot 2011; 69(12): 1904-6. DOI: 10.1016/j.apradiso.2011.03.028

20. Trigano $A$, et al. Experimental study of neutron-induced soft errors in modern cardiac pacemakers. J Interv Card Electrophysiol 2012; 33(1): 19-25. DOI: 10.1007/s10840-011-9609-6

21. Nakamura K, et al. Effect of X-ray dose rates higher than $8 \mathrm{~Gy} /$ min on the functioning of cardiac implantable electronic devices. J Radiat Res 2020; 61(3): 419-425. DOI: 10.1093/jrr/rraa016

22. Gelblum DY, Amols H. Implanted cardiac defibrillator care in radiation oncology patient population. Int J Radiat Oncol Biol Phys 2009; 73(5): 1525-31. DOI: 10.1016/j.jjrobp.2008.06.1903

23. Ferrara TBB, Giuseppe Malinverni, Nicola Caria, Elisabetta Garibaldi, et al. Irradiation of pacemakers and cardiodefibrillators in patients submitted to radiotherapy: a clinical experience. Tumori 2010; 96: 76-83, 2010.

24. Soejima $\mathrm{T}$, et al. Radiation therapy in patients with implanted cardiac pacemakers and implantable cardioverter defibrillators: a prospective survey in Japan. J Radiat Res 2011; 52(4): 516-21. DOI: 10.1269/jrr.10143

25. Brouillard E, et al. Radiation Therapy-Induced Dysfunction in Cardiovascular Implantable Electronic Devices. Pract Radiat Oncol 2019; 9(4): 266-273. DOI: 10.1016/j.prro.2019.03.003

26. Oshiro $Y$, et al. Proton beam therapy interference with implanted cardiac pacemakers. Int J Radiat Oncol Biol Phys 2008; 72(3): 7237. DOI: 10.1016/j.ijrobp.2008.01.062

27. Gomez DR, et al. Malfunctions of implantable cardiac devices in patients receiving proton beam therapy: incidence and predictors. Int J Radiat Oncol Biol Phys 2013; 87(3): 570-5. DOI: 10.1016/j. ijrobp.2013.07.010

28. Seidensaal K, et al. Active-Scanned Protons and Carbon Ions in Cancer Treatment of Patients With Cardiac Implantable Electronic Devices: Experience of a Single Institution. Front Oncol 2019; 9: 798. DOI: $10.3389 /$ fonc. 2019.00798 